\title{
Trojan Horses and Fake Immunity Idols: Molecular Mimicry of Host Immune Mediators by Human Cytomegalovirus
}

\author{
Juliet V. Spencer \\ University of San Francisco \\ United States of America
}

\section{Introduction}

Over the past 20 years, a fundamental shift has occurred in the study of virus-host relations. As scientists first began to identify and appreciate the clever tricks viral pathogens used to hide from the immune system, the terms immune evasion and immune avoidance became prevalent in the literature. More recently, we began to recognize and appreciate just how sophisticated and cunning some of these clever little tricks were, and the term immune modulation took center stage. This implies, correctly, that viruses are not just cowering in dark corners to avoid immune detection by the host, but rather that they are actively manipulating host conditions to create situations that favor virus persistence and make virus clearance difficult or even impossible.

\subsection{Human cytomegalovirus and its bag of tricks}

Once known as "salivary gland virus", HCMV was first isolated from the salivary glands and kidneys of a dying infant with greatly enlarged cells, or cytomegalic inclusion bodies, in affected tissues (Brennan, 2001). A member of the beta subgroup of the Herpesviridae family, HCMV is composed of a large double-stranded DNA genome surrounded by an icosahedral capsid. The linear genome of approximately $230 \mathrm{~kb}$ has terminal repeats flanking two unique segments, designated unique long (UL) and unique short (US), with open reading frames in each segment numbered sequentially. The nucleocapsid is covered by a protein layer termed the tegument, and the entire particle, approximately $200 \mathrm{~nm}$ in diameter, is enclosed by a membrane envelope featuring numerous glycoprotein spikes. HCMV infects multiple cell types, including epithelial cells, fibroblasts, monocytes, macrophages, and lymphocytes. The virus is transmitted between individuals via all body fluids (saliva, blood, breast milk, semen), as well as through bone marrow and solid organ transplants.

Infection with HCMV is often asymptomatic in the healthy host and a large percentage of the general population is seropositive (Staras et al., 2006). In contrast, serious disease frequently occurs in the immune suppressed. Diagnoses of life-threatening HCMV pneumonitis and retinitis are increasing among transplant recipients and persons living with AIDS (de la Hoz et al., 2002). Congenital HCMV infection is the leading viral cause of deafness and mental retardation in newborn infants (Damato and Winnen, 2002). 
Like other herpesviruses, at some point following initial infection, HCMV establishes latent infection. Latency may be defined as the inability to detect infectious virus, despite the presence of viral DNA. All of the specific sites for HCMV latency are not well characterized, but myeloid progenitor cells in the bone marrow are believed to be the main reservoir of latent virus (Sinclair, 2008). Latent genomes have been detected in mononuclear cells in the peripheral blood, but not in neutrophils and other peripheral blood cells (Taylor-Wiedeman et al., 1993; Taylor-Wiedeman et al., 1991).

HCMV encodes over 180 genes, but only a subset of these is required for basic replication and generation of infectious progeny virions (Yu et al., 2003). The remaining viral genes have roles in mediating various aspects of the interaction between the virus and the host. Cellular processes that are affected by CMV gene products include the cell cycle, apoptosis, and immune recognition and response.

HCMV has developed numerous mechanisms for manipulating the host immune system (Scalzo et al., 2007). The virally encoded US2, US3, US6 and US11 gene products all interfere with antigen processing and presentation, resulting in reduced major histocompatibility complex (MHC) class I presentation (Ahn et al., 1996). This causes decreased recognition by cytotoxic T lymphocytes, which was recently found to enable superinfection by multiple virus strains in the same individual (Hansen et al., 2010). In addition, the UL18 gene product is a homolog of the MHC class I protein that is postulated to act as a decoy on the cell surface to assist in the evasion of natural killer cells (Beck and Barrell, 1988).

This chapter will focus on four HCMV genes: UL111A, UL144, UL146, and US28 (Figure 1). These genes encode a viral cytokine, cytokine receptor, chemokine, and chemokine receptor, respectively. Before expanding on each of these viral genes, an introduction to the human cytokine and chemokine system and its importance in immune responses is briefly discussed.

\subsection{Cytokines, chemokines, and their receptors - Critical immune mediators}

During World War II, the United States used the Navajo language to keep military communications from being intercepted by the enemy. Because the Navajo language had never been written down, it was virtually indecipherable without the help of a native speaker. The human immune system, on the other hand, relies on a system of secreted proteins to mediate the interactions required to coordinate and mount an effective immune response. Hundreds of different cytokines are constantly being secreted to regulate, stimulate, suppress, and control the many aspects of cell development, inflammation, and immunity.

Cytokines are produced by a wide variety of cell types, including monocytes, macrophages, lymphocytes, fibroblasts, mast cells, platelets, and the endothelial cells lining the walls of the blood vessels. Release of cytokines is an effective way to send information to multiple cells simultaneously, and only cells with the appropriate receptor can receive the signal, usually by binding to the cytokine at the plasma membrane and then transmitting the signal inside the cell via cellular pathways. Chemokines are a subtype of cytokine that function mainly as chemoattractants to induce migration of immune cells; in fact, the name is a contraction of the term "chemotactic cytokine". When released into the bloodstream, chemokines help to recruit monocytes, neutrophils, and other immune effector cells to sites of infection or damage. Chemokine receptors on target cells have seven transmembrane domains and belong to the G-protein coupled receptor superfamily. 


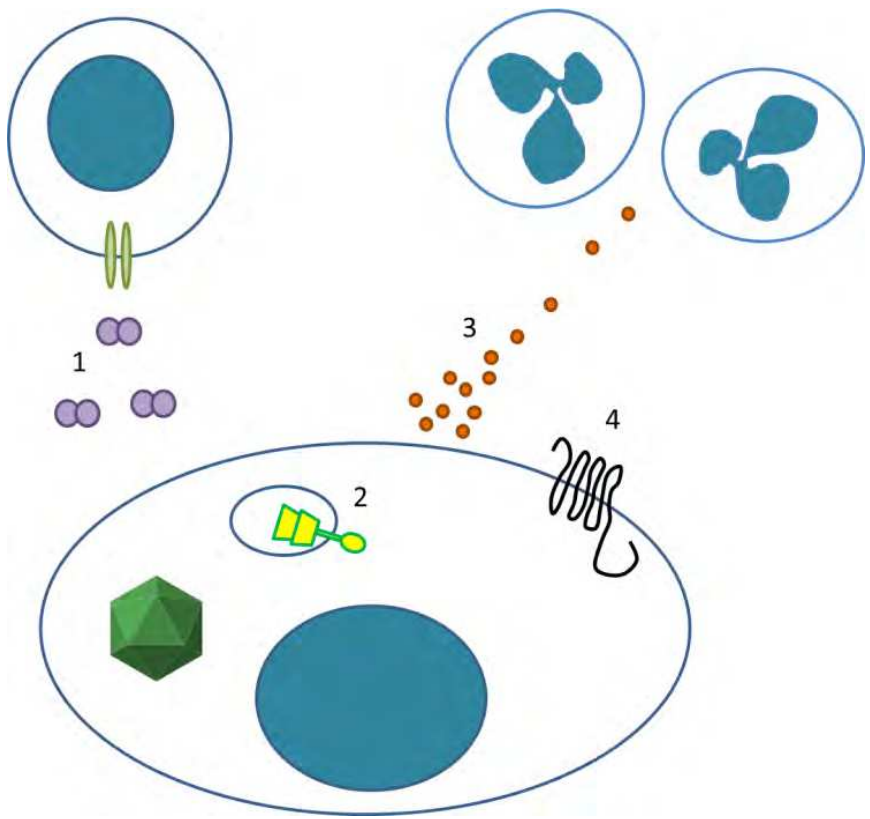

Fig. 1. An HCMV-infected cell displaying immunomodulatory viral proteins. 1) The UL111A gene product, cmvIL-10, is secreted from infected cells and binds to the cellular IL10 receptor as a dimer. 2) The UL144 gene product is a TNF receptor homolog found primarily inside the cell. 3) The UL146 gene product, vCXC-1, is secreted and acts as an $\alpha$ chemokine to attract neutrophils. 4) The US28 gene product is a seven-transmembrane chemokine receptor. A green icosahedron represents a virus nucleocapsid.

Despite its many complexities, the human cytokine system is not nearly as effective as the Navajo language was at confounding the enemy. Viruses like HCMV have not only broken the code, they produce their own cytokines, chemokines, and receptors during the course of infection to claim victory. Or, in viral terms, they render host immune responses ineffective and maintain persistent infection.

\section{The UL111A gene product: CMV IL-10}

Human cellular interleukin-10 (IL-10) is a pleiotropic cytokine that is important to the regulation of the immune response (Mosser and Zhang, 2008). Although stimulatory effects on the proliferation of B cells and mast cells have been reported, the primary function of IL10 appears to be limiting the inflammatory response, in part by opposing interferon gamma (IFN $\gamma$ ) mediated effects. While IL-10 has effects on many cell types, monocytes in particular are a major target for IL-10 activity. IL-10 inhibits production of many cytokines by activated monocytes, including IL- $1 \alpha$, IL-1 $\beta$, IL-6, TNF $\alpha$, and even IL-10 itself (de Waal Malefyt et al., 1991a). Inhibition of IL-1 and TNF $\alpha$ are crucial to the anti-inflammatory effect, as these cytokines can have synergistic effects on other inflammatory pathways. Various cell surface molecules are also down-regulated by IL-10, including class II MHC and co-stimulatory molecules (de Waal Malefyt et al., 1991b), contributing to decreased T cell effector activity. A 
virally controlled IL-10 would enable the virus to direct immune activity to its advantage by inhibiting inflammation and evading $\mathrm{T}$ cell detection, thus providing a window of opportunity in which more virus could be produced and transmitted to other cells (Slobedman et al., 2009).

\subsection{Gene structure and expression}

The UL111 gene was originally designated as the coding region for ORF79, a 79 amino acid protein (Chee et al., 1990a). Another protein product from this region of the viral genome was later identified through searches for possible homologs to human IL-10 (Kotenko et al., 2000; Lockridge et al., 2000). Three exons separated by intervening sequences were identified and found to give rise to a 175 amino acid protein product with $27 \%$ identity to human IL-10 which has been designated cmvIL-10 (Figure 2). Interestingly, a homolog of IL10 was identified in the genome of Epstein-Barr Virus a decade earlier, but the BCRF1 gene lacked introns and gave rise to a protein with $90 \%$ amino acid sequence identity to human IL-10 (Hsu et al., 1990). The human IL-10 gene, which is located on chromosome 1, is comprised of four introns and five exons.

The UL111A gene was found to be expressed with late kinetics in productively infected cells (Lockridge et al., 2000). The cmvIL-10 protein is secreted at sufficient levels to induce serum antibody responses in infected individuals (de Lemos Rieper et al., 2011). In addition to the full length cmvIL-10 protein, an alternative transcript is also produced from the UL111A gene, giving rise to a 139 amino acid protein (Jenkins et al., 2004). The smaller protein, designated LAcmvIL-10, results from read-through of the second intron and then premature termination. LAcmvIL-10 is co-linear with cmvIL-10 for the first 127 residues, then diverges in sequence at C-terminal domain (Figure 3). The name LAcmvIL-10 was based on the observation that this

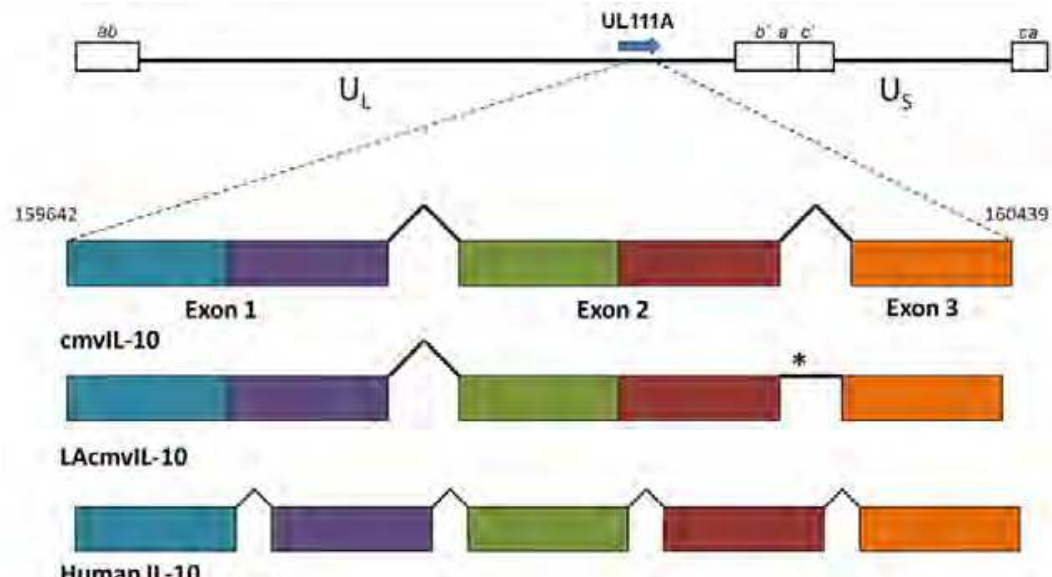

Human IL-10

ebviL-10

Fig. 2. Structure of the UL111A gene. The UL111A gene has two introns, but the organization is similar to the human IL-10 gene, which has four introns, and the ebvIL-10 gene, which has no introns. Also shown is the transcript for the LAcmvIL-10 gene, which reads through the second intron and encounters a stop codon, indicated by the asterisk $\left(^{*}\right)$. 
shorter transcript was initially detected during latent infection of granulocytemacrophage progenitors (and was therefore latency associated). However, it was subsequently found that LAcmvIL-10 is expressed during productive infection as well (Jenkins et al., 2008a). While the transcript encoding full length cmvIL-10 is expressed with late kinetics during infection, the transcript encoding LAcmvIL-10 is expressed with early kinetics during productive infection and continues to be expressed during latent infection.

\subsection{Cell signaling}

Despite having only $27 \%$ sequence identity to human IL-10, cmvIL-10 binds to the cellular IL-10 receptor and displays many of the immune suppressive functions of cellular IL-10 (Slobedman et al., 2009; Spencer et al., 2002). IL-10 effects are mediated via interaction with the cellular IL-10 receptor, a member of the interferon receptor superfamily, which consists of two subunits, a ligand binding subunit (IL-10R1) and a signaling subunit (IL10R2), as shown in Figure 4. The IL-10/IL-10R interaction engages the Janus-family tyrosine kinases Jak1 and Tyk2, which are constitutively associated with IL-10R1 and IL10R2, respectively. Ligand-induced oligomerization results in Jak1 activation leading to phosphorylation of the intercellular IL-10R1 chains. The transcription factor Stat (signal transducer and activator of transcription) is then recruited to the receptor complexes based on specific interaction of Stat $\mathrm{SH} 2$ domains with phosphotyrosine motifs in the receptor. Stats become phosphorylated, dissociate from receptor, form homo-or heterodimers, and translocate to the nucleus. IL-10 binding induces activation of Stat3, leading to suppression of IFN $\gamma$-inducible genes, such as those encoding class II MHC antigens (Donnelly et al., 1999; Mosser and Zhang, 2008).

CmvIL-10 engagement of the IL-10 receptors also leads to Stat3 activation (Spencer, 2007). Downstream immunomodulatory effects include inhibition of PBMC proliferation and inflammatory cytokine production, down-regulation of class I and class II MHC molecules, and impaired dendritic cell maturation (Chang et al., 2009; Chang et al., 2004; Raftery et al., 2001; Raftery et al., 2004; Spencer et al., 2002). Although Stat3 phosphorylation is mediated by Jak1, inhibition of cytokine synthesis also involves signaling through the phosphatidylinositol 3-kinase (PI3K) pathway (Spencer, 2007). Additional studies have shown that cmvIL-10 can inhibit NF-KB signaling in monocytes (Nachtwey and Spencer, 2008). Like human IL-10, the cmvIL-10 protein forms a dimer, and evidence suggests that cmvIL-10 can form heterodimers with human IL-10 that actually enhance Stat3 phosphorylation (Lin et al., 2008).

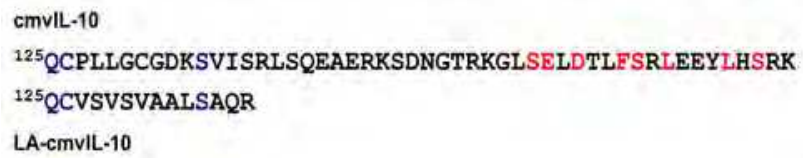

Fig. 3. Amino acid sequence comparison of the C-terminal domain of full length cmvIL-10 and LAcmvIL-10. The proteins are identical from amino acids 1-127. Identical residues are shown in blue; residues that contact the cellular IL-10 receptor are shown in red.

LAcmvIL-10 retains some but not all of the immune suppressive properties of full length cmvIL-10 (Jenkins et al., 2008b; Spencer et al., 2008). LAcmvIL-10 can trigger down-regulation of class II MHC from the surface of monocytes and granulocyte-macrophage progenitor cells; however, this effect does not involve Stat3 phosphorylation and is independent of the IL-10 
receptor. In addition, LAcmvIL-10 failed to inhibit maturation of dendritic cells and had no impact on the expression of co-stimulatory molecules (Jenkins et al., 2008b).

\subsection{Role in infection}

The UL111A gene is not required for virus replication in vitro, which supports the notion that cmvIL-10 and LAcmvIL-10 probably function in modifying host immune responses in vivo (Avdic et al., 2011). Studies with a UL111A deletion mutant virus have shown up-regulation of cytokines involved in dendritic cell formation and a higher proportion of myeloid dendritic cells compared to wild type virus. The results suggest that the UL111A gene products actively limit the ability of the host to respond to infection and clear virus, which is consistent with the observations of other groups that IL-10 is a key determinant of virus persistence (Brooks et al., 2008; Brooks et al., 2006). Vaccination studies of rhesus macaques also support the notion that the IL-10 pathway plays an important role in virus clearance (Barry, 2011). The Rhesus CMV genome also encodes an IL-10 homolog, designated RhcmvIL-10 (Lockridge et al., 2000). Uninfected rhesus macaques were immunized with a strategy designed to prevent engagement of the cellular IL-10 receptor by RhcmvIL-10 (Barry, 2011). Upon challenge with RhCMV, vaccinated animals had significantly fewer infected cells and infiltrate at the inoculation site, as well as reduced levels of virus in saliva and urine compared to control animals. Therapeutic strategies that neutralize cmvIL-10 activity hold great potential for enhancing the control or elimination of this persistent pathogen.

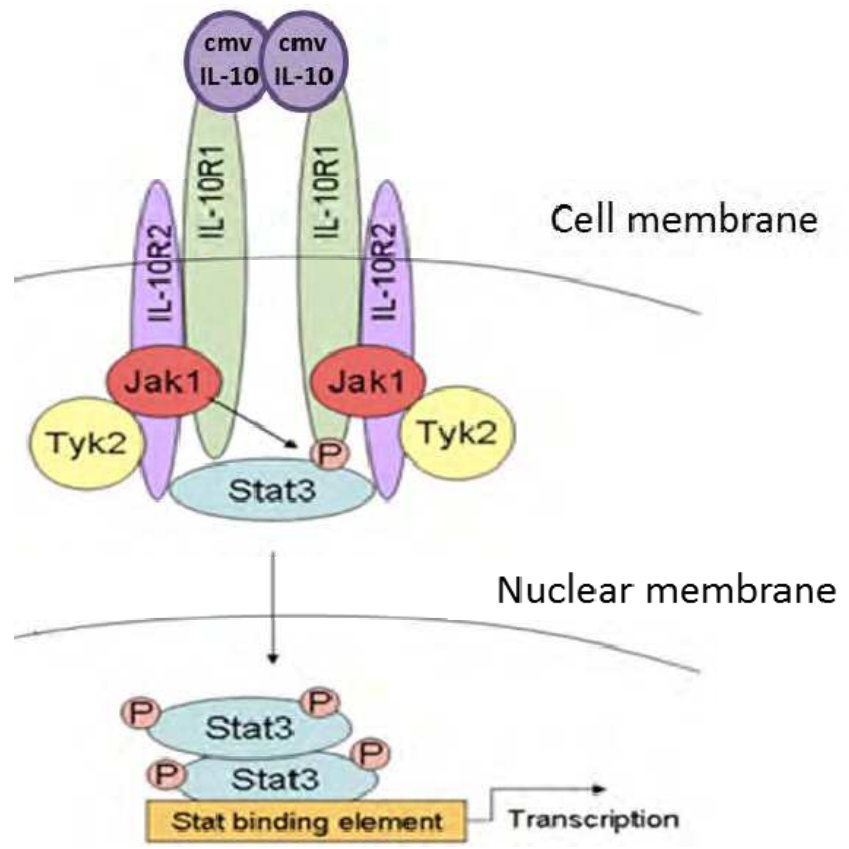

Fig. 4. Depiction of cmvIL-10 signaling through the cellular IL-10 receptor. The viral cytokine binds as a dimer, pulling together receptor chains to create a functional tetrameric receptor complex. The receptor associated kinase JAK1 phosphorylates Stat3, which then dimerizes and translocates to the nucleus to stimulate gene transcription. 


\subsection{Role in latent infection}

Expression of the UL111A gene plays a role in maintaining a reservoir of virus by protecting latently infected cells from CD4+ $\mathrm{T}$ cell recognition (Cheung et al., 2009). A UL111A deletion mutant virus was able to establish latent infection in myeloid progenitor cells and also reactivate from latency just as effectively as wild type virus. However, cells infected with the deletion mutant expressed higher levels of class II MHC on the cell surface. This effect was confirmed to be due to the lack of viral IL-10, since the addition of recombinant IL-10 (both full length cmvIL-10 and LAcmvIL-10) resulted in lower levels of class II MHC expression that was comparable to that of cells infected with wild type virus. Reduced class II expression correlated with diminished CD4 T cell responses, as measured by proliferation and interferon- $\gamma$ production by purified allogeneic CD4 $\mathrm{T}$ cells co-cultured with the infected cells. CD4+T cells cultured with cells infected with the UL111A deletion virus exhibited significantly higher levels of proliferation and cytokine production, suggesting that UL111A gene products limit recognition of HCMV-infected cells by CD4+ T cells, thereby enhancing the pool of latently infected cells.

\subsection{Role in cancer}

The possible relationship between HCMV and cancer has been investigated for some time. The development of more sensitive detection methods has recently shown a very strong link between HCMV infection and glioblastoma and prostate cancer (Cobbs et al., 2002; Cobbs et al., 2007; Mitchell et al., 2008; Samanta et al., 2003). While HCMV is not generally regarded as an oncogenic virus, the term oncomodulation has been proposed to describe the increased malignancy associated with HCMV-infected tumor cells (Michaelis et al., 2009). The possible molecular mechanisms for oncomodulation include altered cell cycle regulation by immediate early proteins IE1 and IE2 (Sanchez and Spector, 2008), which promote entry into S phase, as well as the activity of the UL97 protein, which phosphorylates and inactivates tumor suppressor $\mathrm{Rb}$ (Hume et al., 2008). In addition, the UL36, UL37, and UL38 gene products all interfere with caspase function and convey resistance to apoptosis (McCormick, 2008; Skaletskaya et al., 2001). HCMV-infected neuroblastoma cells have been observed to down-regulate adhesion molecules and exhibit increased motility (Blaheta et al., 2004). In infected prostate cancer and glioma cells, HCMV infection resulted in increased migration and invasion that was dependent on phosphorylation of focal adhesion kinase (FAK) (Blaheta et al., 2006; Cobbs et al., 2007). Most recently, evidence points to a role of cmvIL-10 in promoting cancer progression.

HCMV has been shown to infect both glioma cancer stem cells (gCSCs) and macrophage/migroglial populations present in malignant gliomas (Dziurzynski et al., 2011). Production of cmvIL-10 by the gCSCs may convert peripheral blood monocytes into an immune suppressive, tumor-promoting cell type. The cmvIL-10 present in gCSC conditioned medium was shown to trigger activation of Stat 3 and production of immune suppressive cytokines (Dziurzynski et al., 2011). At this point, the tumor promoting role of cmvIL-10 is largely associated with activation of Stat3. The Stat3 pathway is known to be active in a number of cell types in the tumor microenvironment and contributes to general immune suppression hindering anti-tumor responses (Kortylewski et al., 2005). In a murine model of glioma, Stat3 has been demonstrated to promote an influx of macrophages, which correlated negatively with survival (Kong et al., 2010). In addition, Stat3 activation is associated with poor prognosis in ovarian cancer and considered a key factor in metastasis 
formation and chemo-resistance (Zhang et al., 2010). This is one of the most exciting new areas of research involving cmvIL-10, and additional studies are currently underway to define the role of cmvIL-10 in potentiating tumor progression.

\section{The UL144 gene product: TNF receptor homolog}

Tumor necrosis factor (TNF) is an inflammatory cytokine that exists in both a membranebound and soluble form (Caminero et al., 2011). The biological effects of this cytokine are mediated through interactions with two receptors, TNF receptor 1 (TNFR1) and TNF receptor 2 (TNFR2). TNFR1 is expressed in a wide variety of cell types whereas TNFR2 is expressed only in cells of the immune system. Ligand-binding induces receptor trimerization and conformational changes that lead to dissociation of the inhibitory protein suppressor of death domain (SODD) followed by association of TRADD, or TNFR associated death domain protein (Wajant et al., 2003). Following TRADD binding, there are several possible outcomes, including activation of the NF-кB pathway, activation of the MAPK pathway, or induction of apoptosis. Both HSV-1 and HCMV target the TNF pathway (Figure 5); HSV-1 through glycoprotein D (Montgomery et al., 1996) and a TNFR homolog, HVEM (herpesvirus entry mediator) and HCMV through the UL144 gene product, also a TNFR homolog (Benedict et al., 1999; Cheung et al., 2005).

\subsection{Gene structure and expression}

The UL144 gene is one contiguous open reading frame located in the ULb' region of the HCMV genome (Figure 6). This region contains 19 ORFs first identified in the Toledo strain that are found in other clinical isolates yet deleted from laboratory strains (Cha et al., 1996). The UL144 gene product was identified through database searches and has regions of homology with the TNF receptor superfamily, especially the herpesvirus entry mediator, HVEM (Benedict et al., 1999), although the UL144 protein does not facilitate entry by HSV-1. UL144 is expressed early in HCMV infection with protein detected four hours post-infection (Benedict et al., 1999). Transcription from the UL144 gene is complex, with at least four differentially regulated transcripts expressed (He et al., 2011). One of these transcripts encompasses UL142 through UL145, and all transcripts contain both UL144 and UL145. Recent evidence also suggests that the UL144 gene is expressed by specific viral strains during experimental models of latency (Poole, 2011).

\subsection{Cell signaling}

The UL144 gene gives rise to a 176 amino acid protein with a transmembrane domain and short cytoplasmic tail. Despite the presence of an N-terminal signal sequence and multiple $\mathrm{N}$-linked glycosylation sites in the ectodomain, the protein appears to be retained in an intracellular compartment (Benedict et al., 1999). Retention is mediated by tyrosine based sorting motif at the C-terminus of the protein (aa 173-176, YRTL), as demonstrated by a Y173A mutant expressed in 293T cells that displayed significantly higher levels of cell surface protein. The protein also contains two cysteine rich domains (CRDs) which are characteristic of TNFR family members, although many family members have as many as four CRDs. The CRD-2 region of the UL144 protein also shares significant homology with the ligand binding domain of another TNFR family member, TRAIL-R2. Although no TNF family ligands have been found to bind to the UL144 receptor, a member of the 
immunoglobulin superfamily known as BLTA, for B and T lymphocyte attenuator, was identified as a ligand for UL144 (Cheung et al., 2005). Presumably the UL144 protein would have to present on the cell surface in order to mediate this signaling. Despite its apparent intracellular localization, the UL144 protein must be exposed at some point during the infection since antibodies to this protein can be detected in HIV and HCMV co-infected individuals (Benedict et al., 1999).

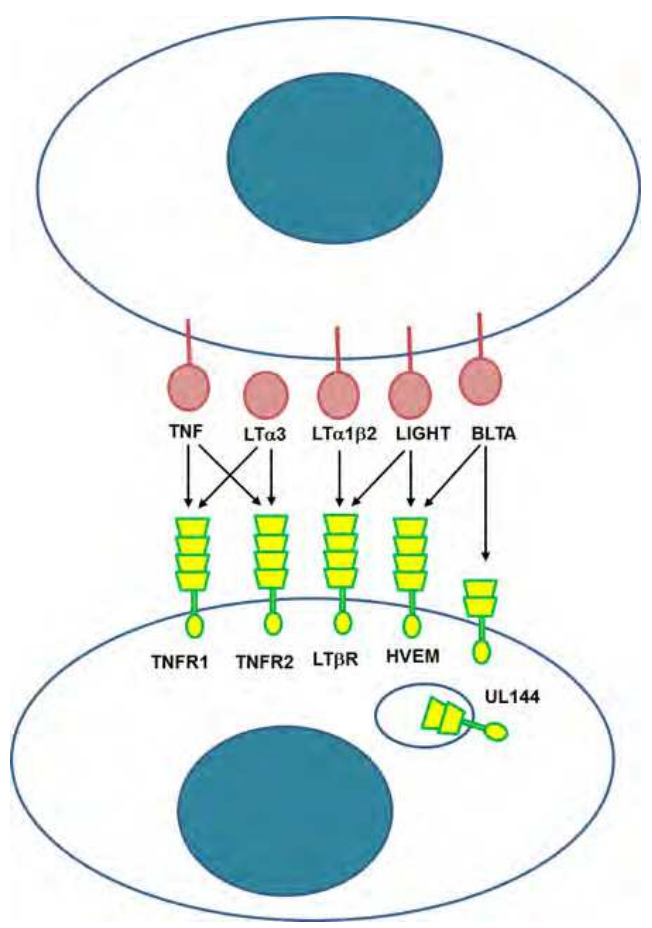

Fig. 5. TNF receptor superfamily members and their ligands. HVEM is the herpesvirus entry mediator of HSV-1. The UL144 gene product of HCMV is predominantly found inside the cell, but could interact with BLTA if present on the cell surface. Yellow trapezoids represent the CRD (cysteine rich domains) conserved throughout the TNFR superfamily.

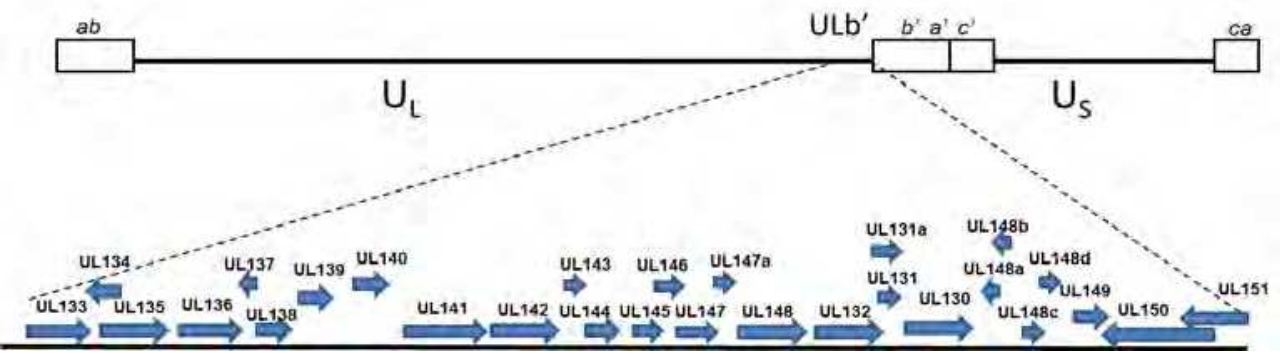

Fig. 6. Organization of the ULb' region of the HCMV Toledo strain genome. 


\subsection{Role in infection}

In addition to the inhibitory effects on T-cell activation through engagement of BLTA (Cheung et al., 2005), UL144 also serves as an immune modulator during infection by triggering production of CCL22/MDC (or macrophage-derived chemokine) (Poole et al., 2008; Poole et al., 2006). CCL22 was detected in the supernatants from cells infected with a Toledo strain virus, but not in supernatants from cells infected with AD169, which lacks the ULb' region. This effect was found to be mediated by NF- $\kappa B$ and is dependent on TRAF (TNFR associated factor). Induction of CCL22, which attracts Th2 and regulatory $\mathrm{T}$ cells expressing the CCR4 receptor (Yoshie et al., 2001), may aid in thwarting host immune responses by antagonizing the more effective TH1 antiviral response. The LMP1 protein of EBV also induces CCL2 expression (Nakayama et al., 2004), suggesting yet another common mechanism for manipulation of host responses among herpesviruses.

\subsection{Polymorphisms as a measure of virulence}

There have been conflicting reports regarding the correlation between UL144 genotype and clinical outcome. Genes in the ULb' region, and the UL144 gene in particular, show a high level of variability among clinical strains. Three main genotypes have been described based on the extracellular region of the UL144 protein: type A, type B, and type C (Arav-Boger et al., 2006; Lurain et al., 1999). While some groups found that polymorphisms in the UL144 gene were not predictive of clinical outcome (Bale et al., 2001; Heo et al., 2008), others have found that types A and C do correlate with higher viral load and clinical sequelae (AravBoger et al., 2006; Waters et al., 2010). Differences in outcome may be attributable to sample size and population. Additionally, to date studies have been conducted only on congenitally infected infants, and so it is not clear how UL144 strain polymorphisms correlate with disease in other patient populations, such as transplant recipients or persons with HIV/AIDS.

\section{The UL146 gene product: $\alpha$-chemokine vCXC-1}

Chemokines are a family of small soluble proteins that are secreted by immune cells in response to infection (Salazar-Mather and Hokeness, 2006). Members of the chemokine family fall mainly into one of two categories: $\alpha$-chemokines or $\beta$-chemokines. The $\beta$ chemokines induce migration of monocytes, natural killer cells, and dendritic cells; they have two adjacent cysteines near the amino terminus of the protein and are also known as CC chemokines. In contrast, $\alpha$-chemokines induce chemotaxis of neutrophils; they have the two cysteines separated by one amino acid and are known as CXC chemokines. CXC chemokines also generally have an ELR motif (glutamic acid - leucine - arginine) before the first cysteine. Interleukin- 8 was the first CXC chemokine discovered, although its systemic designation is CXCL8. It is produced mainly by monocytes and lymphocytes, and it functions to induce neutrophil chemotaxis and degranulation through the chemokine receptors $\mathrm{CXCR} 1$ and $\mathrm{CXCR} 2$. Chemokines are important for controlling virus infection because they direct immune cells to sites of infection. However, for viruses that infect immune cells, chemokines may provide a vehicle for attracting host cells, or for directing infected cells to distribute virus to other parts of the body (Lusso, 2000; Murphy, 2001). 


\subsection{Gene structure, expression, and signaling}

The UL146 gene, which is also located in the ULb' region of the HCMV genome (Figure 6), encodes a functional $\alpha$-chemokine (Penfold et al., 1999). The UL146 gene is expressed with late kinetics during infection and gives rise to a 117 amino acid protein. The protein contains an N-terminal signal sequence as well as the ELRCXC motif found in IL-8 that is known to be important for neutrophil binding and activation (Clark-Lewis et al., 1991). The UL146 gene product, which is also known as vCXC-1, was found to induce calcium flux and migration of neutrophils (Penfold et al., 1999). Since neutrophils express both CXCR1 and CXCR2, cells expressing each receptor separately were employed to dissect which receptor was mediating the effects of vCXC-1. While the initial studies identified CXCR2 as the primary receptor (Penfold et al., 1999), subsequent studies have found that vCXC-1 also binds to and effectively signals through the CXCR1 receptor (Luttichau, 2010). Although the adjacent gene, UL147, has a CXC motif, it lacks the ELR sequence and has not been shown to elicit signaling through human chemokine receptors (Penfold et al., 1999).

\subsection{Role in infection}

The UL146 gene product has been shown to encode a potent $\alpha$-chemokine that induces neutrophil migration, calcium mobilization, and degranulation (Luttichau, 2010; Penfold et al., 1999). While it has been suggested that UL146 may function to recruit neutrophils to sites of infection to provide a vehicle for virus dissemination to distant sites in the body (Figure 7), this has yet to be examined in the context of virus infection in vivo, mainly because the species specificity of HCMV remains a barrier to its use with animal models. As discussed earlier, there is one model system that is particularly well-suited for investigating CMV-host interactions; the natural infection of Rhesus macaques (Macaca mulatta) by RhCMV (Powers and Fruh, 2008).

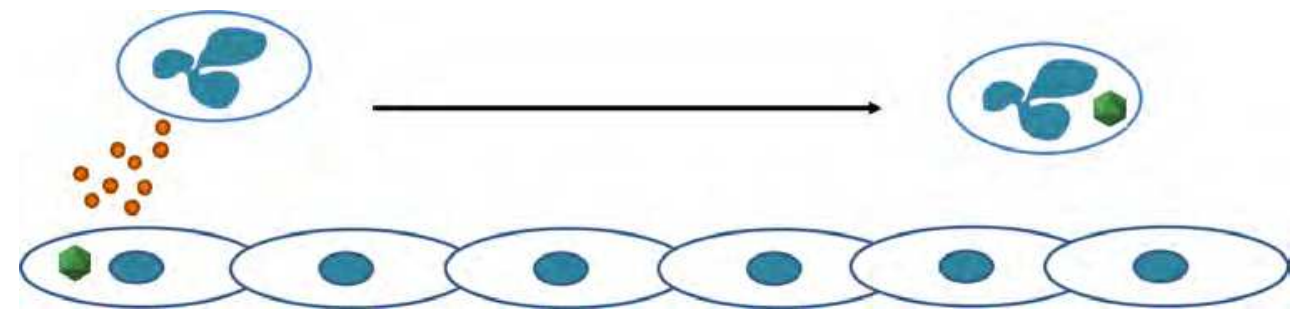

Fig. 7. Possible role for vCXC-1 in virus dissemination. Virus infected cells attract neutrophils via secretion of vCXC-1. Neutrophils could either become infected or phagocytose infected cells, then travel through the bloodstream, transporting virus to distant sites in the body.

The human and rhesus macaque genomes share about $95 \%$ sequence similarity. The complete genome of RhCMV strain 68.1 was sequenced in 2003, revealing 230 potential open reading frames, of which 138 were homologous to known HCMV proteins (Hansen et al., 2003). A more pathogenic isolate, RhCMV strain 180.92, was subsequently sequenced, revealing 10 additional open reading frames (Rivailler et al., 2006). A consensus map of both strains reveals that they each contain open reading frame designated Rh157.4, which was identified as having some homology to HCMV UL146 (Oxford et al., 2008). Most recently, RhCMV strains isolated from naturally infected macaques have recently been found to contain an additional genome 
segment not found in laboratory strains (Oxford et al., 2008). This segment, located between the Rh157.4 gene and the Rh161 gene, contains three open reading frames encoding proteins that exhibit $21-44 \%$ amino acid sequence identity with human IL-8 and/or HCMV UL146. Each of these three genes contains the ELRCXC motif (or a closely related sequence). Interestingly, these new genes (designated Rh161a, b, and c) also have homology to Rh161, which itself has low-level homology with human IL-8, suggesting that a gene duplication event may have occurred. Including RhUL146 and RhUL147 (rh158), this makes a total of 6 genes with homology to $\alpha$-chemokines encoded by RhCMV. It is unclear why the virus would require six $\alpha$-chemokine genes; however, such gene duplication events have been reported, notably in the case of the RhCMV US28 locus, where only one of the five genes was found to encode a functional receptor (Penfold et al., 2003). Additional studies are ongoing to determine which of these RhCMV genes encode functional chemokines and to discern their role in virus infection in vivo.

\subsection{Polymorphisms as a measure of virulence}

Like the UL144 gene, divergence of the UL146 has been noted in a large number of clinical strains (Aguayo et al., 2010; Arav-Boger et al., 2008; Bradley et al., 2008; He et al., 2006; Heo et al., 2008). In two of these studies, no connection between UL146 polymorphisms and clinical disease was noted (He et al., 2006; Heo et al., 2008). Arav-Boger et al developed an artificial neural network system to analyze variability of four different CMV genes (US28, UL144, UL146, and UL147) from congenitally infected infants in the Unites States and Italy (Arav-Boger et al., 2008). The results showed that UL144 and UL146 predicted the outcome of CMV disease in more than $80 \%$ of cases, when used separately, and specific nucleotide positions played a key role in these analyses. Despite the high degree of sequence variation noted for UL146, chemokine functionality is generally retained (Prichard et al., 2001).

\section{The US28 gene product: Chemokine receptor}

Chemokine receptors belong to the GPCR superfamily, one of the largest families of cell surface receptors. Receptors of this type relay signals from the cell surface to intracellular effectors and are found in all eukaryotic cells, from yeast to man. The human genome encodes over a thousand GPCRs, including receptors in the visual, olfactory, and gustatory (taste) systems, as well as many neurotransmitter, hormone, and chemokine receptors (Pierce et al., 2002). Members of this superfamily interact with heterotrimeric intracellular $G$ proteins comprising $\alpha, \beta$, and $\gamma$-subunits. In the inactive state, the G $\alpha$ subunit binds to GDP (Gether, 2000). However, upon ligand binding, a conformational change occurs that promotes association of the intracellular domain of the receptor with a G-protein and catalyzes the exchange of GTP for bound GDP in the Ga subunit. Following receptor activation, the GTP-G $\alpha$ subunit dissociates from both the receptor and the $\beta \gamma$ subunits, which bind to each other very tightly. Each subunit can then interact with and activate specific downstream cellular effectors, depending on the nature of the receptor-ligand interaction. Intrinsic GTPase activity in the Ga subunit converts it to the inactive GDPbound form, and re-association of the heterotrimeric complex terminates the signal and restores the receptor to its resting state. In addition to ligand dependent signaling, some GPCR, including HCMV US28, have been shown to signal in a ligand-independent, constitutive manner (Casarosa et al., 2001; Vischer et al., 2006a; Waldhoer et al., 2002). 


\subsection{Gene structure and expression}

Of the four genes described here, only US28 was identified in the initial sequencing of the genome of HCMV strain AD169 (Chee et al., 1990a). Found within the unique short region of the HCMV genome, US28 is one of four genes with homology to the cellular G-protein coupled receptor (GPCR) superfamily (Chee et al., 1990b). Of the four HCMV GPCR (UL33, UL78, US27, and US28), only US28 has been shown to be a bona fide chemokine receptor. US28 has been extensively studied and is the subject of numerous reviews (Beisser et al., 2008; Vischer andLeurs and Smit, 2006a; Vischer et al., 2006b; Vomaske et al., 2009); only a brief overview of the current literature on US28 is provided here.

Expression of US28 transcripts occurs throughout the infection cycle, at immediate early, early, and late time points (Bodaghi et al., 1998; Zipeto et al., 1999), as well as during latency in THP-1 monocytes (Beisser et al., 2001). Although no homologs of this receptor exist in the genomes of rodent CMVs, five tandem homologs of US28 have been identified in the genome of Rhesus CMV (Penfold et al., 2003).

Because US27 and US28 are directly adjacent to one another in the HCMV genome and share $31 \%$ sequence identity, there has been some speculation that the two are a result of a gene duplication event. There is evidence for expression of both proteins in infected cells (FraileRamos et al., 2001; Fraile-Ramos et al., 2002), suggesting that each receptor may have evolved (or is evolving) a distinct role in viral pathogenesis. US28 is expressed throughout the lytic and latent infection cycle, while US27 is expressed late in lytic infection only (Beisser et al., 2001; Welch et al., 1991), indicating that the two genes are independently regulated.

\subsection{Cell signaling}

US28 has been shown to bind to several human chemokines, including CX3CL/fractalkine, CCL5/RANTES, CCL3/MIP-1 $\alpha$, CCL2/MCP-1, and CCL7/MCP-3 (Beisser et al., 2002; Gao and Murphy, 1994; Neote et al., 1993). In addition, US28 is promiscuous in G protein coupling and has been shown to signal through $G \alpha_{q}, G \alpha_{i / o}, G \alpha_{12}$, and $G \alpha_{16}$ (Billstrom et al., 1998; Casarosa et al., 2001; Melnychuk et al., 2004). Chemokine binding to US28 induces a wide range of intracellular responses, including calcium mobilization, MAP kinase activation, cell migration, and activation of transcription factors such as NFAT, CREB, and NF- $\mathrm{KB}$ (Billstrom et al., 1998; Casarosa et al., 2001; Gao and Murphy, 1994; Streblow et al., 2003; Vieira et al., 1998). NF-кB activation has been shown to stimulate IL-6 production followed by a cascade including Stat3 phosphorylation and VEGF production (Figure 7) (Slinger et al., 2010).

Ligand-independent signaling has been found to include constitutive phospholipase $\mathrm{C}$ activation and inositol phosphate $\left(\mathrm{IP}_{3}\right)$ production (Casarosa et al., 2001; Minisini et al., 2003). US28 can also promote cell-cell fusion (Pleskoff et al., 1998) and was found to serve as a co-factor for entry of HIV into CD4+ cells (Pleskoff et al., 1997).

For some types of GPCR, most notably the $\gamma$-aminobutyric acid (GABA) receptor, dimerization has been documented to be critical for effector activation and signaling (Kaupmann et al., 1998; Kuner et al., 1999; White et al., 1998). Chemokine receptors have also been shown to form functional dimers and oligomers that affect different aspects of receptor physiology, such as ligand affinity and signal transduction (Kramp et al., 2011; Mellado et al., 2001). Recent evidence suggests that US28 forms multimers with other GPCR (Tschische et al., 2011). UL33 and UL78 were both able to block US28-mediated activation of the transcription factor NF- $\mathrm{kB}$, although constitutive signaling via the Gaq/phospholipase C pathway by US28 was not affected by receptor heteromerization (Tschische et al., 2011). 


\subsection{Role in infection}

Despite the extensive in vitro characterization of US28, discerning a role for this protein in vivo during infection has been difficult since rodent CMVs do not encode a US28 homolog. However, murine CMV does encode homologs of two other HCMV GPCR, UL33 and UL78 (M33 and M78, respectively), suggesting that perhaps these genes were hijacked from an ancient host by an ancestral virus. Recent studies have shown that MCMV mutants lacking M33 exhibit a replication defect resulting in a significant reduction in virus replication in the salivary gland, as well as reduced reactivation from tissue explants (Farrell et al., 2011). Interestingly, HCMV US28 was found to complement the M33 mutant virus and restore both salivary gland replication and explant reactivation. These findings support the widely held view that the US28 receptor aids in virus dissemination by enabling infected cells to respond to chemokines and transport virus to distant sites in the body.

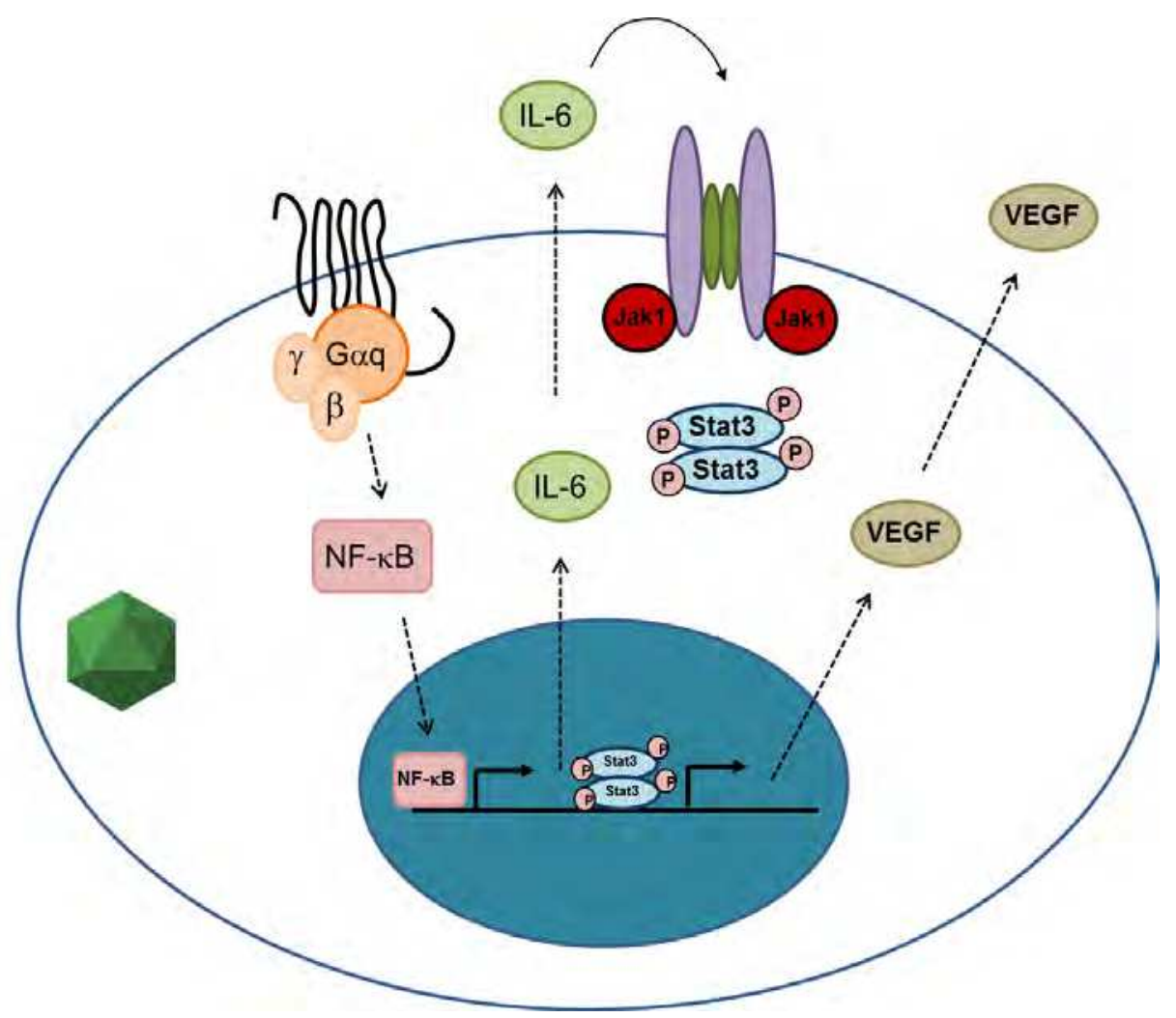

Fig. 8. US28 activates NF-kB inducing IL-6 expression. IL-6 can bind to its receptor in either an autocrine manner, as shown above, or act on nearby cells in a paracrine manner, to stimulate Stat 3 and induce VEGF. 


\subsection{Role in atherosclerosis and cancer}

The formation of atherosclerotic plaques resembles a chronic inflammatory response characterized by infiltration of monocytes, macrophages, and Tymphocytes recruited to the site via the secretion of chemokines from the vascular endothelium (Gautier et al., 2009; Zernecke and Weber, 2010). Both molecular and epidemiological data strongly links HCMV infection to atherosclerosis (Cheng et al., 2009; Epstein et al., 2009; Froberg et al., 2001; Gredmark-Russ et al., 2009; Hendrix et al., 1990; Hosenpud, 1999; Mattila et al., 1998; Straat et al., 2009; Streblow et al., 2008; Streblow et al., 2001a; Yi et al., 2008). Significant evidence now supports the notion that US28 may exacerbate atherosclerotic plaque formation by enhancing smooth muscle cell migration, and this subject has been reviewed elsewhere (Melnychuk et al., 2004; Streblow et al., 2001b; Streblow et al., 2007; Streblow et al., 1999; Streblow et al., 2003; Vischer andLeurs and Smit, 2006a).

In addition to a potential role in cardiovascular disease, HCMV infection has also been implicated in several types of cancer (see section 2.5). In particular, US28-expressing cells have been shown to promote tumorigenesis when injected into mice (Maussang et al., 2006). Activation of NF- $\kappa B$ by US28 contributed to increased expression of cyclooxygenase-2 (COX-2), an inflammatory mediator that plays a central role in several types of cancer (Maussang et al., 2009). Activation of Stat3 via the same pathway also has implications for cancer development, as previously discussed. Therapeutics blocking US28 activity may have utility for a number of diseases.

\section{Conclusion}

HCMV is endemic in the human population and may be associated with various human diseases. Most of the time, however, the virus peacefully co-exists with its human host. This interaction is governed by viral gene products that take an active role in establishing latency and modifying host immune responses in favor of virus persistence. Like the mythical Trojan horse that enabled the Greeks to conquer Troy, HCMV encodes many genes that seem innocuous, yet may have the power to decisively determine the outcome of virus infection.

\section{References}

Aguayo, F., Murayama, T., and Eizuru, Y. (2010). UL146 variability among clinical isolates of human cytomegalovirus from Japan. Biol Res 43(4), 475-80.

Ahn, K., Angulo, A., Ghazal, P., Peterson, P. A., Yang, Y., and Fruh, K. (1996). Human cytomegalovirus inhibits antigen presentation by a sequential multistep process. Proc Natl Acad Sci U S A 93(20), 10990-5.

Arav-Boger, R., Battaglia, C. A., Lazzarotto, T., Gabrielli, L., Zong, J. C., Hayward, G. S., Diener-West, M., and Landini, M. P. (2006). Cytomegalovirus (CMV)-encoded UL144 (truncated tumor necrosis factor receptor) and outcome of congenital CMV infection. J Infect Dis 194(4), 464-73.

Arav-Boger, R., Boger, Y. S., Foster, C. B., and Boger, Z. (2008). The use of artificial neural networks in prediction of congenital CMV outcome from sequence data. Bioinform Biol Insights 2, 281-9.

Avdic, S., Cao, J. Z., Cheung, A. K., Abendroth, A., and Slobedman, B. (2011). Viral Interleukin-10 Expressed by Human Cytomegalovirus during the Latent Phase of 
Infection Modulates Latently Infected Myeloid Cell Differentiation. J Virol 85(14), 7465-71.

Bale, J. F., Jr., Petheram, S. J., Robertson, M., Murph, J. R., and Demmler, G. (2001). Human cytomegalovirus a sequence and UL144 variability in strains from infected children. J Med Virol 65(1), 90-6.

Barry, P. A., M. Eberhardt, and M. Walter (2011). Targeting the IL-10 Signaling Pathway as a Vaccine Strategy for HCMV. In "13th International CMV/Betaherpesvirus Workshop", Nuremburg, Germany.

Beck, S., and Barrell, B. G. (1988). Human cytomegalovirus encodes a glycoprotein homologous to MHC class-I antigens. Nature 331(6153), 269-72.

Beisser, P. S., Goh, C. S., Cohen, F. E., and Michelson, S. (2002). Viral chemokine receptors and chemokines in human cytomegalovirus trafficking and interaction with the immune system. CMV chemokine receptors. Curr Top Microbiol Immunol 269, 20334.

Beisser, P. S., Laurent, L., Virelizier, J. L., and Michelson, S. (2001). Human cytomegalovirus chemokine receptor gene US28 is transcribed in latently infected THP-1 monocytes. J Virol 75(13), 5949-57.

Beisser, P. S., Lavreysen, H., Bruggeman, C. A., and Vink, C. (2008). Chemokines and chemokine receptors encoded by cytomegaloviruses. Curr Top Microbiol Immunol 325, 221-42.

Benedict, C. A., Butrovich, K. D., Lurain, N. S., Corbeil, J., Rooney, I., Schneider, P., Tschopp, J., and Ware, C. F. (1999). Cutting edge: a novel viral TNF receptor superfamily member in virulent strains of human cytomegalovirus. J Immunol 162(12), 6967-70.

Billstrom, M. A., Johnson, G. L., Avdi, N. J., and Worthen, G. S. (1998). Intracellular signaling by the chemokine receptor US28 during human cytomegalovirus infection. J Virol 72(7), 5535-44.

Blaheta, R. A., Weich, E., Marian, D., Bereiter-Hahn, J., Jones, J., Jonas, D., Michaelis, M., Doerr, H. W., and Cinatl, J., Jr. (2006). Human cytomegalovirus infection alters PC3 prostate carcinoma cell adhesion to endothelial cells and extracellular matrix. Neoplasia 8(10), 807-16.

Bodaghi, B., Jones, T. R., Zipeto, D., Vita, C., Sun, L., Laurent, L., Arenzana-Seisdedos, F., Virelizier, J. L., and Michelson, S. (1998). Chemokine sequestration by viral chemoreceptors as a novel viral escape strategy: withdrawal of chemokines from the environment of cytomegalovirus-infected cells. J Exp Med 188(5), 855-66.

Bradley, A. J., Kovacs, I. J., Gatherer, D., Dargan, D. J., Alkharsah, K. R., Chan, P. K., Carman, W. F., Dedicoat, M., Emery, V. C., Geddes, C. C., Gerna, G., Ben-Ismaeil, B., Kaye, S., McGregor, A., Moss, P. A., Pusztai, R., Rawlinson, W. D., Scott, G. M., Wilkinson, G. W., Schulz, T. F., and Davison, A. J. (2008). Genotypic analysis of two hypervariable human cytomegalovirus genes. J Med Virol 80(9), 1615-23.

Brennan, D. C. (2001). Cytomegalovirus in renal transplantation. J Am Soc Nephrol 12(4), 84855.

Brooks, D. G., Lee, A. M., Elsaesser, H., McGavern, D. B., and Oldstone, M. B. (2008). IL-10 blockade facilitates DNA vaccine-induced $\mathrm{T}$ cell responses and enhances clearance of persistent virus infection. J Exp Med 205(3), 533-41. 
Brooks, D. G., Trifilo, M. J., Edelmann, K. H., Teyton, L., McGavern, D. B., and Oldstone, M. B. (2006). Interleukin-10 determines viral clearance or persistence in vivo. Nat Med 12(11), 1301-9.

Caminero, A., Comabella, M., and Montalban, X. (2011). Tumor necrosis factor alpha (TNFalpha), anti-TNF-alpha and demyelination revisited: an ongoing story. $J$ Neuroimmunol 234(1-2), 1-6.

Casarosa, P., Bakker, R. A., Verzijl, D., Navis, M., Timmerman, H., Leurs, R., and Smit, M. J. (2001). Constitutive signaling of the human cytomegalovirus-encoded chemokine receptor US28. J Biol Chem 276(2), 1133-7.

Cha, T. A., Tom, E., Kemble, G. W., Duke, G. M., Mocarski, E. S., and Spaete, R. R. (1996). Human cytomegalovirus clinical isolates carry at least 19 genes not found in laboratory strains. J Virol 70(1), 78-83.

Chang, W. L., Barry, P. A., Szubin, R., Wang, D., and Baumgarth, N. (2009). Human cytomegalovirus suppresses type I interferon secretion by plasmacytoid dendritic cells through its interleukin 10 homolog. Virology 390(2), 330-7.

Chang, W. L., Baumgarth, N., Yu, D., and Barry, P. A. (2004). Human cytomegalovirusencoded interleukin-10 homolog inhibits maturation of dendritic cells and alters their functionality. J Virol 78(16), 8720-31.

Chee, M. S., Bankier, A. T., Beck, S., Bohni, R., Brown, C. M., Cerny, R., Horsnell, T., Hutchison, C. A., 3rd, Kouzarides, T., Martignetti, J. A., and et al. (1990a). Analysis of the protein-coding content of the sequence of human cytomegalovirus strain AD169. Curr Top Microbiol Immunol 154, 125-69.

Chee, M. S., Satchwell, S. C., Preddie, E., Weston, K. M., and Barrell, B. G. (1990b). Human cytomegalovirus encodes three $\mathrm{G}$ protein-coupled receptor homologues. Nature 344(6268), 774-7.

Cheng, J., Ke, Q., Jin, Z., Wang, H., Kocher, O., Morgan, J. P., Zhang, J., and Crumpacker, C. S. (2009). Cytomegalovirus infection causes an increase of arterial blood pressure. PLoS Pathog 5(5), e1000427.

Cheung, A. K., Gottlieb, D. J., Plachter, B., Pepperl-Klindworth, S., Avdic, S., Cunningham, A. L., Abendroth, A., and Slobedman, B. (2009). The role of the human cytomegalovirus UL111A gene in down-regulating CD4+ T-cell recognition of latently infected cells: implications for virus elimination during latency. Blood 114(19), 4128-37.

Cheung, T. C., Humphreys, I. R., Potter, K. G., Norris, P. S., Shumway, H. M., Tran, B. R., Patterson, G., Jean-Jacques, R., Yoon, M., Spear, P. G., Murphy, K. M., Lurain, N. S., Benedict, C. A., and Ware, C. F. (2005). Evolutionarily divergent herpesviruses modulate $\mathrm{T}$ cell activation by targeting the herpesvirus entry mediator cosignaling pathway. Proc Natl Acad Sci U S A 102(37), 13218-23.

Clark-Lewis, I., Schumacher, C., Baggiolini, M., and Moser, B. (1991). Structure-activity relationships of interleukin-8 determined using chemically synthesized analogs. Critical role of NH2-terminal residues and evidence for uncoupling of neutrophil chemotaxis, exocytosis, and receptor binding activities. J Biol Chem 266(34), 2312834.

Cobbs, C. S., Harkins, L., Samanta, M., Gillespie, G. Y., Bharara, S., King, P. H., Nabors, L. B., Cobbs, C. G., and Britt, W. J. (2002). Human cytomegalovirus infection and expression in human malignant glioma. Cancer Res 62(12), 3347-50. 
Cobbs, C. S., Soroceanu, L., Denham, S., Zhang, W., Britt, W. J., Pieper, R., and Kraus, M. H. (2007). Human cytomegalovirus induces cellular tyrosine kinase signaling and promotes glioma cell invasiveness. J Neurooncol 85(3), 271-80.

Damato, E. G., and Winnen, C. W. (2002). Cytomegalovirus infection: perinatal implications. J Obstet Gynecol Neonatal Nurs 31(1), 86-92.

de la Hoz, R. E., Stephens, G., and Sherlock, C. (2002). Diagnosis and treatment approaches of CMV infections in adult patients. J Clin Virol 25 Suppl 2, S1-12.

de Lemos Rieper, C., Galle, P., Pedersen, B. K., and Hansen, M. B. (2011). Characterization of specific antibodies against cytomegalovirus (CMV)-encoded interleukin 10 produced by $28 \%$ of CMV-seropositive blood donors. J Gen Virol 92(Pt 7), 1508-18.

de Waal Malefyt, R., Abrams, J., Bennett, B., Figdor, C. G., and de Vries, J. E. (1991a). Interleukin 10(IL-10) inhibits cytokine synthesis by human monocytes: an autoregulatory role of IL-10 produced by monocytes. J Exp Med 174(5), 1209-20.

de Waal Malefyt, R., Haanen, J., Spits, H., Roncarolo, M. G., te Velde, A., Figdor, C., Johnson, K., Kastelein, R., Yssel, H., and de Vries, J. E. (1991b). Interleukin 10 (IL-10) and viral IL-10 strongly reduce antigen-specific human $\mathrm{T}$ cell proliferation by diminishing the antigen-presenting capacity of monocytes via downregulation of class II major histocompatibility complex expression. J Exp Med 174(4), 915-24.

Donnelly, R. P., Dickensheets, H., and Finbloom, D. S. (1999). The interleukin-10 signal transduction pathway and regulation of gene expression in mononuclear phagocytes. J Interferon Cytokine Res 19(6), 563-73.

Dziurzynski, K., Wei, J., Qiao, W., Hatiboglu, M. A., Kong, L. Y., Wu, A., Wang, Y., Cahill, D., Levine, N. B., Prabhu, S., Rao, G., Sawaya, R., and Heimberger, A. B. (2011). Glioma-associated cytomegalovirus mediates subversion of the monocyte lineage to a tumor propagating phenotype. Clin Cancer Res.

Epstein, S. E., Zhu, J., Najafi, A. H., and Burnett, M. S. (2009). Insights into the role of infection in atherogenesis and in plaque rupture. Circulation 119(24), 3133-41.

Farrell, H. E., Abraham, A. M., Cardin, R. D., Sparre-Ulrich, A. H., Rosenkilde, M. M., Spiess, K., Jensen, T. H., Kledal, T. N., and Davis-Poynter, N. (2011). Partial functional complementation between human and mouse cytomegalovirus chemokine receptor homologues. J Virol 85(12), 6091-5.

Fraile-Ramos, A., Kledal, T. N., Pelchen-Matthews, A., Bowers, K., Schwartz, T. W., and Marsh, M. (2001). The human cytomegalovirus US28 protein is located in endocytic vesicles and undergoes constitutive endocytosis and recycling. Mol Biol Cell 12(6), 1737-49.

Fraile-Ramos, A., Pelchen-Matthews, A., Kledal, T. N., Browne, H., Schwartz, T. W., and Marsh, M. (2002). Localization of HCMV UL33 and US27 in endocytic compartments and viral membranes. Traffic 3(3), 218-32.

Froberg, M. K., Adams, A., Seacotte, N., Parker-Thornburg, J., and Kolattukudy, P. (2001). Cytomegalovirus infection accelerates inflammation in vascular tissue overexpressing monocyte chemoattractant protein-1. Circ Res 89(12), 1224-30.

Gao, J. L., and Murphy, P. M. (1994). Human cytomegalovirus open reading frame US28 encodes a functional beta chemokine receptor. J Biol Chem 269(46), 28539-42.

Gautier, E. L., Jakubzick, C., and Randolph, G. J. (2009). Regulation of the migration and survival of monocyte subsets by chemokine receptors and its relevance to atherosclerosis. Arterioscler Thromb Vasc Biol 29(10), 1412-8. 
Gether, U. (2000). Uncovering molecular mechanisms involved in activation of G proteincoupled receptors. Endocr Rev 21(1), 90-113.

Gredmark-Russ, S., Dzabic, M., Rahbar, A., Wanhainen, A., Bjorck, M., Larsson, E., Michel, J. B., and Soderberg-Naucler, C. (2009). Active cytomegalovirus infection in aortic smooth muscle cells from patients with abdominal aortic aneurysm. J Mol Med 87(4), 347-56.

Hansen, S. G., Powers, C. J., Richards, R., Ventura, A. B., Ford, J. C., Siess, D., Axthelm, M. K., Nelson, J. A., Jarvis, M. A., Picker, L. J., and Fruh, K. (2010). Evasion of CD8+ T cells is critical for superinfection by cytomegalovirus. Science 328(5974), 102-6.

Hansen, S. G., Strelow, L. I., Franchi, D. C., Anders, D. G., and Wong, S. W. (2003). Complete sequence and genomic analysis of rhesus cytomegalovirus. J Virol 77(12), 6620-36.

He, R., Ma, Y., Qi, Y., Wang, N., Li, M., Ji, Y., Sun, Z., Jiang, S., and Ruan, Q. (2011). Characterization of the Transcripts of Human Cytomegalovirus UL144. Virol J 8(1), 299.

He, R., Ruan, Q., Qi, Y., Ma, Y. P., Huang, Y. J., Sun, Z. R., and Ji, Y. H. (2006). Sequence variability of human cytomegalovirus UL146 and UL147 genes in low-passage clinical isolates. Intervirology 49(4), 215-23.

Hendrix, M. G., Salimans, M. M., van Boven, C. P., and Bruggeman, C. A. (1990). High prevalence of latently present cytomegalovirus in arterial walls of patients suffering from grade III atherosclerosis. Am J Pathol 136(1), 23-8.

Heo, J., Petheram, S., Demmler, G., Murph, J. R., Adler, S. P., Bale, J., and Sparer, T. E. (2008). Polymorphisms within human cytomegalovirus chemokine (UL146/UL147) and cytokine receptor genes (UL144) are not predictive of sequelae in congenitally infected children. Virology 378(1), 86-96.

Hosenpud, J. D. (1999). Coronary artery disease after heart transplantation and its relation to cytomegalovirus. Am Heart J 138(5 Pt 2), S469-72.

Hsu, D. H., de Waal Malefyt, R., Fiorentino, D. F., Dang, M. N., Vieira, P., de Vries, J., Spits, H., Mosmann, T. R., and Moore, K. W. (1990). Expression of interleukin-10 activity by Epstein-Barr virus protein BCRF1. Science 250(4982), 830-2.

Hume, A. J., Finkel, J. S., Kamil, J. P., Coen, D. M., Culbertson, M. R., and Kalejta, R. F. (2008). Phosphorylation of retinoblastoma protein by viral protein with cyclindependent kinase function. Science 320(5877), 797-9.

Jenkins, C., Abendroth, A., and Slobedman, B. (2004). A Novel Viral Transcript with Homology to Human Interleukin-10 Is Expressed during Latent Human Cytomegalovirus Infection. J Virol 78(3), 1440-7.

Jenkins, C., Garcia, W., Abendroth, A., and Slobedman, B. (2008a). Expression of a human cytomegalovirus latency-associated homolog of interleukin-10 during the productive phase of infection. Virology 370(2), 285-94.

Jenkins, C., Garcia, W., Godwin, M. J., Spencer, J. V., Stern, J. L., Abendroth, A., and Slobedman, B. (2008b). Immunomodulatory properties of a viral homolog of human interleukin-10 expressed by human cytomegalovirus during the latent phase of infection. J Virol 82(7), 3736-50.

Kaupmann, K., Malitschek, B., Schuler, V., Heid, J., Froestl, W., Beck, P., Mosbacher, J., Bischoff, S., Kulik, A., Shigemoto, R., Karschin, A., and Bettler, B. (1998). GABA(B)receptor subtypes assemble into functional heteromeric complexes. Nature 396(6712), 683-7. 
Kong, L. Y., Wu, A. S., Doucette, T., Wei, J., Priebe, W., Fuller, G. N., Qiao, W., Sawaya, R., Rao, G., and Heimberger, A. B. (2010). Intratumoral mediated immunosuppression is prognostic in genetically engineered murine models of glioma and correlates to immunotherapeutic responses. Clin Cancer Res 16(23), 5722-33.

Kortylewski, M., Kujawski, M., Wang, T., Wei, S., Zhang, S., Pilon-Thomas, S., Niu, G., Kay, H., Mule, J., Kerr, W. G., Jove, R., Pardoll, D., and Yu, H. (2005). Inhibiting Stat3 signaling in the hematopoietic system elicits multicomponent antitumor immunity. Nat Med 11(12), 1314-21.

Kotenko, S. V., Saccani, S., Izotova, L. S., Mirochnitchenko, O. V., and Pestka, S. (2000). Human cytomegalovirus harbors its own unique IL-10 homolog (cmvIL-10). Proc Natl Acad Sci U S A 97(4), 1695-700.

Kramp, B. K., Sarabi, A., Koenen, R. R., and Weber, C. (2011). Heterophilic chemokine receptor interactions in chemokine signaling and biology. Exp Cell Res 317(5), 65563.

Kuner, R., Kohr, G., Grunewald, S., Eisenhardt, G., Bach, A., and Kornau, H. C. (1999). Role of heteromer formation in GABAB receptor function. Science 283(5398), 74-7.

Lin, Y. L., Chang, P. C., Wang, Y., and Li, M. (2008). Identification of novel viral interleukin10 isoforms of human cytomegalovirus AD169. Virus Res 131(2), 213-23.

Lockridge, K. M., Zhou, S. S., Kravitz, R. H., Johnson, J. L., Sawai, E. T., Blewett, E. L., and Barry, P. A. (2000). Primate cytomegaloviruses encode and express an IL-10-like protein. Virology 268(2), 272-80.

Lurain, N. S., Kapell, K. S., Huang, D. D., Short, J. A., Paintsil, J., Winkfield, E., Benedict, C. A., Ware, C. F., and Bremer, J. W. (1999). Human cytomegalovirus UL144 open reading frame: sequence hypervariability in low-passage clinical isolates. J Virol 73(12), 10040-50.

Lusso, P. (2000). Chemokines and viruses: the dearest enemies. Virology 273(2), 228-40.

Luttichau, H. R. (2010). The cytomegalovirus UL146 gene product vCXCL1 targets both CXCR1 and CXCR2 as an agonist. J Biol Chem 285(12), 9137-46.

Mattila, K. J., Valtonen, V. V., Nieminen, M. S., and Asikainen, S. (1998). Role of infection as a risk factor for atherosclerosis, myocardial infarction, and stroke. Clin Infect Dis 26(3), 719-34.

Maussang, D., Langemeijer, E., Fitzsimons, C. P., Stigter-van Walsum, M., Dijkman, R., Borg, M. K., Slinger, E., Schreiber, A., Michel, D., Tensen, C. P., van Dongen, G. A., Leurs, R., and Smit, M. J. (2009). The human cytomegalovirus-encoded chemokine receptor US28 promotes angiogenesis and tumor formation via cyclooxygenase- 2 . Cancer Res 69(7), 2861-9.

Maussang, D., Verzijl, D., van Walsum, M., Leurs, R., Holl, J., Pleskoff, O., Michel, D., van Dongen, G. A., and Smit, M. J. (2006). Human cytomegalovirus-encoded chemokine receptor US28 promotes tumorigenesis. Proc Natl Acad Sci U S A 103(35), 13068-73.

McCormick, A. L. (2008). Control of apoptosis by human cytomegalovirus. Curr Top Microbiol Immunol 325, 281-95.

Mellado, M., Rodriguez-Frade, J. M., Vila-Coro, A. J., Fernandez, S., Martin de Ana, A., Jones, D. R., Toran, J. L., and Martinez, A. C. (2001). Chemokine receptor homo- or heterodimerization activates distinct signaling pathways. Embo J 20(10), 2497-507. 
Melnychuk, R. M., Streblow, D. N., Smith, P. P., Hirsch, A. J., Pancheva, D., and Nelson, J. A. (2004). Human cytomegalovirus-encoded G protein-coupled receptor US28 mediates smooth muscle cell migration through Galpha12. J Virol 78(15), 8382-91.

Michaelis, M., Doerr, H. W., and Cinatl, J. (2009). The story of human cytomegalovirus and cancer: increasing evidence and open questions. Neoplasia 11(1), 1-9.

Minisini, R., Tulone, C., Luske, A., Michel, D., Mertens, T., Gierschik, P., and Moepps, B. (2003). Constitutive inositol phosphate formation in cytomegalovirus-infected human fibroblasts is due to expression of the chemokine receptor homologue pUS28. J Virol 77(8), 4489-501.

Mitchell, D. A., Xie, W., Schmittling, R., Learn, C., Friedman, A., McLendon, R. E., and Sampson, J. H. (2008). Sensitive detection of human cytomegalovirus in tumors and peripheral blood of patients diagnosed with glioblastoma. Neuro Oncol 10(1), 10-8.

Montgomery, R. I., Warner, M. S., Lum, B. J., and Spear, P. G. (1996). Herpes simplex virus-1 entry into cells mediated by a novel member of the TNF/NGF receptor family. Cell 87(3), 427-36.

Mosser, D. M., and Zhang, X. (2008). Interleukin-10: new perspectives on an old cytokine. Immunol Rev 226, 205-18.

Murphy, P. M. (2001). Viral exploitation and subversion of the immune system through chemokine mimicry. Nat Immunol 2(2), 116-22.

Nachtwey, J., and Spencer, J. V. (2008). HCMV IL-10 suppresses cytokine expression in monocytes through inhibition of nuclear factor-kappaB. Viral Immunol 21(4), 477-82.

Nakayama, T., Hieshima, K., Nagakubo, D., Sato, E., Nakayama, M., Kawa, K., and Yoshie, O. (2004). Selective induction of Th2-attracting chemokines CCL17 and CCL22 in human B cells by latent membrane protein 1 of Epstein-Barr virus. J Virol 78(4), 1665-74.

Neote, K., DiGregorio, D., Mak, J. Y., Horuk, R., and Schall, T. J. (1993). Molecular cloning, functional expression, and signaling characteristics of a C-C chemokine receptor. Cell 72(3), 415-25.

Oxford, K. L., Eberhardt, M. K., Yang, K. W., Strelow, L., Kelly, S., Zhou, S. S., and Barry, P. A. (2008). Protein coding content of the UL)b' region of wild-type rhesus cytomegalovirus. Virology 373(1), 181-8.

Penfold, M. E., Dairaghi, D. J., Duke, G. M., Saederup, N., Mocarski, E. S., Kemble, G. W., and Schall, T. J. (1999). Cytomegalovirus encodes a potent alpha chemokine. Proc Natl Acad Sci U S A 96(17), 9839-44.

Penfold, M. E., Schmidt, T. L., Dairaghi, D. J., Barry, P. A., and Schall, T. J. (2003). Characterization of the rhesus cytomegalovirus US28 locus. J Virol 77(19), 10404-13.

Pierce, K. L., Premont, R. T., and Lefkowitz, R. J. (2002). Seven-transmembrane receptors. Nat Rev Mol Cell Biol 3(9), 639-50.

Pleskoff, O., Treboute, C., and Alizon, M. (1998). The cytomegalovirus-encoded chemokine receptor US28 can enhance cell-cell fusion mediated by different viral proteins. $J$ Virol 72(8), 6389-97.

Pleskoff, O., Treboute, C., Brelot, A., Heveker, N., Seman, M., and Alizon, M. (1997). Identification of a chemokine receptor encoded by human cytomegalovirus as a cofactor for HIV-1 entry. Science 276(5320), 1874-8.

Poole, E., Atkins, E., Nakayama, T., Yoshie, O., Groves, I., Alcami, A., and Sinclair, J. (2008). NF-kappaB-mediated activation of the chemokine CCL22 by the product of the 
human cytomegalovirus gene UL144 escapes regulation by viral IE86. J Virol 82(9), 4250-6.

Poole, E., K. Raven, M. Reeves, J. Sinclair (2011). UL144 is expressed during latency but in a strain specific manner. In "13th International CMV/Betaherpesvirus Workshop", Nuremberg, Germany.

Poole, E., King, C. A., Sinclair, J. H., and Alcami, A. (2006). The UL144 gene product of human cytomegalovirus activates NFkappaB via a TRAF6-dependent mechanism. Embo J 25(18), 4390-9.

Powers, C., and Fruh, K. (2008). Rhesus CMV: an emerging animal model for human CMV. Med Microbiol Immunol 197(2), 109-15.

Prichard, M. N., Penfold, M. E., Duke, G. M., Spaete, R. R., and Kemble, G. W. (2001). A review of genetic differences between limited and extensively passaged human cytomegalovirus strains. Rev Med Virol 11(3), 191-200.

Raftery, M. J., Schwab, M., Eibert, S. M., Samstag, Y., Walczak, H., and Schonrich, G. (2001). Targeting the function of mature dendritic cells by human cytomegalovirus: a multilayered viral defense strategy. Immunity 15(6), 997-1009.

Raftery, M. J., Wieland, D., Gronewald, S., Kraus, A. A., Giese, T., and Schonrich, G. (2004). Shaping phenotype, function, and survival of dendritic cells by cytomegalovirusencoded IL-10. J Immunol 173(5), 3383-91.

Rivailler, P., Kaur, A., Johnson, R. P., and Wang, F. (2006). Genomic sequence of rhesus cytomegalovirus 180.92: insights into the coding potential of rhesus cytomegalovirus. J Virol 80(8), 4179-82.

Salazar-Mather, T. P., and Hokeness, K. L. (2006). Cytokine and chemokine networks: pathways to antiviral defense. Curr Top Microbiol Immunol 303, 29-46.

Samanta, M., Harkins, L., Klemm, K., Britt, W. J., and Cobbs, C. S. (2003). High prevalence of human cytomegalovirus in prostatic intraepithelial neoplasia and prostatic carcinoma. J Urol 170(3), 998-1002.

Sanchez, V., and Spector, D. H. (2008). Subversion of cell cycle regulatory pathways. Curr Top Microbiol Immunol 325, 243-62.

Scalzo, A. A., Corbett, A. J., Rawlinson, W. D., Scott, G. M., and Degli-Esposti, M. A. (2007). The interplay between host and viral factors in shaping the outcome of cytomegalovirus infection. Immunol Cell Biol 85(1), 46-54.

Sinclair, J. (2008). Human cytomegalovirus: Latency and reactivation in the myeloid lineage. J Clin Virol 41(3), 180-5.

Skaletskaya, A., Bartle, L. M., Chittenden, T., McCormick, A. L., Mocarski, E. S., and Goldmacher, V. S. (2001). A cytomegalovirus-encoded inhibitor of apoptosis that suppresses caspase-8 activation. Proc Natl Acad Sci U S A 98(14), 7829-34.

Slinger, E., Maussang, D., Schreiber, A., Siderius, M., Rahbar, A., Fraile-Ramos, A., Lira, S. A., Soderberg-Naucler, C., and Smit, M. J. (2010). HCMV-encoded chemokine receptor US28 mediates proliferative signaling through the IL-6-STAT3 axis. Sci Signal 3(133), ra58.

Slobedman, B., Barry, P. A., Spencer, J. V., Avdic, S., and Abendroth, A. (2009). Virusencoded homologs of cellular interleukin-10 and their control of host immune function. J Virol 83(19), 9618-29. 
Spencer, J. V. (2007). The cytomegalovirus homolog of interleukin-10 requires phosphatidylinositol 3-kinase activity for inhibition of cytokine synthesis in monocytes. J Virol 81(4), 2083-6.

Spencer, J. V., Cadaoas, J., Castillo, P. R., Saini, V., and Slobedman, B. (2008). Stimulation of B lymphocytes by cmvIL-10 but not LAcmvIL-10. Virology 374(1), 164-9.

Spencer, J. V., Lockridge, K. M., Barry, P. A., Lin, G., Tsang, M., Penfold, M. E., and Schall, T. J. (2002). Potent immunosuppressive activities of cytomegalovirus-encoded interleukin-10. J Virol 76(3), 1285-92.

Staras, S. A., Dollard, S. C., Radford, K. W., Flanders, W. D., Pass, R. F., and Cannon, M. J. (2006). Seroprevalence of cytomegalovirus infection in the United States, 1988-1994. Clin Infect Dis 43(9), 1143-51.

Straat, K., de Klark, R., Gredmark-Russ, S., Eriksson, P., and Soderberg-Naucler, C. (2009). Infection with human cytomegalovirus alters the MMP-9/TIMP-1 balance in human macrophages. J Virol 83(2), 830-5.

Streblow, D. N., Dumortier, J., Moses, A. V., Orloff, S. L., and Nelson, J. A. (2008). Mechanisms of cytomegalovirus-accelerated vascular disease: induction of paracrine factors that promote angiogenesis and wound healing. Curr Top Microbiol Immunol 325, 397-415.

Streblow, D. N., Orloff, S. L., and Nelson, J. A. (2001a). Do pathogens accelerate atherosclerosis? J Nutr 131(10), 2798S-2804S.

Streblow, D. N., Orloff, S. L., and Nelson, J. A. (2001b). The HCMV chemokine receptor US28 is a potential target in vascular disease. Curr Drug Targets Infect Disord 1(2), 151-8.

Streblow, D. N., Orloff, S. L., and Nelson, J. A. (2007). Acceleration of allograft failure by cytomegalovirus. Curr Opin Immunol 19(5), 577-82.

Streblow, D. N., Soderberg-Naucler, C., Vieira, J., Smith, P., Wakabayashi, E., Ruchti, F., Mattison, K., Altschuler, Y., and Nelson, J. A. (1999). The human cytomegalovirus chemokine receptor US28 mediates vascular smooth muscle cell migration. Cell 99(5), 511-20.

Streblow, D. N., Vomaske, J., Smith, P., Melnychuk, R., Hall, L., Pancheva, D., Smit, M., Casarosa, P., Schlaepfer, D. D., and Nelson, J. A. (2003). Human cytomegalovirus chemokine receptor US28-induced smooth muscle cell migration is mediated by focal adhesion kinase and Src. J Biol Chem 278(50), 50456-65.

Taylor-Wiedeman, J., Hayhurst, G. P., Sissons, J. G., and Sinclair, J. H. (1993). Polymorphonuclear cells are not sites of persistence of human cytomegalovirus in healthy individuals. J Gen Virol 74 ( Pt 2), 265-8.

Taylor-Wiedeman, J., Sissons, J. G., Borysiewicz, L. K., and Sinclair, J. H. (1991). Monocytes are a major site of persistence of human cytomegalovirus in peripheral blood mononuclear cells. J Gen Virol 72 ( Pt 9), 2059-64.

Tschische, P., Tadagaki, K., Kamal, M., Jockers, R., and Waldhoer, M. (2011). Heteromerization of human cytomegalovirus encoded chemokine receptors. Biochem Pharmacol.

Vieira, J., Schall, T. J., Corey, L., and Geballe, A. P. (1998). Functional analysis of the human cytomegalovirus US28 gene by insertion mutagenesis with the green fluorescent protein gene. J Virol 72(10), 8158-65. 
Vischer, H. F., Leurs, R., and Smit, M. J. (2006a). HCMV-encoded G-protein-coupled receptors as constitutively active modulators of cellular signaling networks. Trends Pharmacol Sci 27(1), 56-63.

Vischer, H. F., Vink, C., and Smit, M. J. (2006b). A viral conspiracy: hijacking the chemokine system through virally encoded pirated chemokine receptors. Curr Top Microbiol Immunol 303, 121-54.

Vomaske, J., Nelson, J. A., and Streblow, D. N. (2009). Human Cytomegalovirus US28: a functionally selective chemokine binding receptor. Infect Disord Drug Targets 9(5), 548-56.

Wajant, H., Pfizenmaier, K., and Scheurich, P. (2003). Tumor necrosis factor signaling. Cell Death Differ 10(1), 45-65.

Waldhoer, M., Kledal, T. N., Farrell, H., and Schwartz, T. W. (2002). Murine cytomegalovirus (CMV) M33 and human CMV US28 receptors exhibit similar constitutive signaling activities. J Virol 76(16), 8161-8.

Waters, A., Hassan, J., De Gascun, C., Kissoon, G., Knowles, S., Molloy, E., Connell, J., and Hall, W. W. (2010). Human cytomegalovirus UL144 is associated with viremia and infant development sequelae in congenital infection. J Clin Microbiol 48(11), 3956-62.

Welch, A. R., McGregor, L. M., and Gibson, W. (1991). Cytomegalovirus homologs of cellular G protein-coupled receptor genes are transcribed. J Virol 65(7), 3915-8.

White, J. H., Wise, A., Main, M. J., Green, A., Fraser, N. J., Disney, G. H., Barnes, A. A., Emson, P., Foord, S. M., and Marshall, F. H. (1998). Heterodimerization is required for the formation of a functional GABA(B) receptor. Nature 396(6712), 679-82.

Yi, L., Wang, D. X., and Feng, Z. J. (2008). Detection of human cytomegalovirus in atherosclerotic carotid arteries in humans. J Formos Med Assoc 107(10), 774-81.

Yoshie, O., Imai, T., and Nomiyama, H. (2001). Chemokines in immunity. Adv Immunol 78, 57-110.

Yu, D., Silva, M. C., and Shenk, T. (2003). Functional map of human cytomegalovirus AD169 defined by global mutational analysis. Proc Natl Acad Sci U S A 100(21), 12396-401.

Zernecke, A., and Weber, C. (2010). Chemokines in the vascular inflammatory response of atherosclerosis. Cardiovasc Res.

Zhang, X., Liu, P., Zhang, B., Wang, A., and Yang, M. (2010). Role of STAT3 decoy oligodeoxynucleotides on cell invasion and chemosensitivity in human epithelial ovarian cancer cells. Cancer Genet Cytogenet 197(1), 46-53.

Zipeto, D., Bodaghi, B., Laurent, L., Virelizier, J. L., and Michelson, S. (1999). Kinetics of transcription of human cytomegalovirus chemokine receptor US28 in different cell types. J Gen Virol 80 ( Pt 3), 543-7. 


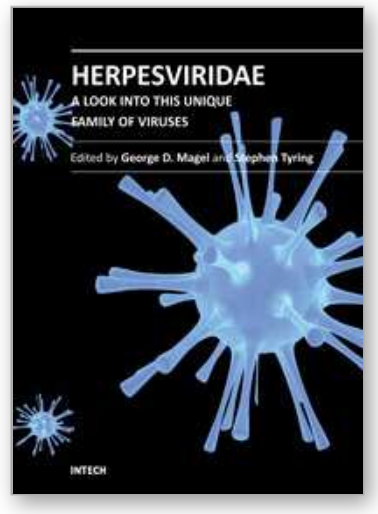

\author{
Herpesviridae - A Look Into This Unique Family of Viruses \\ Edited by Dr. George Dimitri Magel
}

ISBN 978-953-51-0186-4

Hard cover, 320 pages

Publisher InTech

Published online 07, March, 2012

Published in print edition March, 2012

In order to fully understand the nature of viruses, it is important to look at them from both, their basic science and clinical, standpoints. Our goal with this book was to dissect Herpesviridae into its biological properties and clinical significance in order to provide a logical, as well as practical, approach to understanding and treating the various conditions caused by this unique family of viruses. In addition to their up-to-date and extensive text, each chapter is laced with a variety of diagrams, tables, charts, and images, aimed at helping us achieve our goal. We hope that this book will serve as a reference tool for clinicians of various specialties worldwide.

\title{
How to reference
}

In order to correctly reference this scholarly work, feel free to copy and paste the following:

Juliet V. Spencer (2012). Trojan Horses and Fake Immunity Idols: Molecular Mimicry of Host Immune Mediators by Human Cytomegalovirus, Herpesviridae - A Look Into This Unique Family of Viruses, Dr. George Dimitri Magel (Ed.), ISBN: 978-953-51-0186-4, InTech, Available from:

http://www.intechopen.com/books/herpesviridae-a-look-into-this-unique-family-of-viruses/trojan-horses-andfake-immunity-idols-molecular-mimicry-of-host-immune-mediators-by-human-cytomegalo

\section{INTECH}

open science | open minds

\section{InTech Europe}

University Campus STeP Ri

Slavka Krautzeka 83/A

51000 Rijeka, Croatia

Phone: +385 (51) 770447

Fax: +385 (51) 686166

www.intechopen.com

\section{InTech China}

Unit 405, Office Block, Hotel Equatorial Shanghai

No.65, Yan An Road (West), Shanghai, 200040, China

中国上海市延安西路65号上海国际贵都大饭店办公楼405单元

Phone: +86-21-62489820

Fax: +86-21-62489821 
(C) 2012 The Author(s). Licensee IntechOpen. This is an open access article distributed under the terms of the Creative Commons Attribution 3.0 License, which permits unrestricted use, distribution, and reproduction in any medium, provided the original work is properly cited. 